\title{
THE EXPERT WITNESS IN CRIMINAL CASES IN FRANCE, GERMANY, AND ITALY
}

\author{
Morris Ploscowe*
}

The basic character of the criminal procedure in any country determines the position of the expert witness. In France, Germany, and Italy, the procedure is inquisitory as contrasted with the contentious or accusatory Anglo-American procedure. In these three continental countries, an investigating magistrate conducts an impartial judicial inquiry into the most important criminal cases, and prepares them for trial. He is known as the juge d'instruction in France, the Untersuchungsrichter in Germany, and the giudice istruttore in Italy. His mission is to get at the truth of each criminal charge and he therefore gathers evidence both for the prosecution and for the defense. - Being a judicial officer, he is endowed with wide powers of arrest, preventive detention, search and seizure, etc., to aid him in his investigations. The results of his investigations, embodied in written documents, have a profound influence at the trial.

Trial procedure, too, is essentially inquisitory in the three countries under consideration. Although the prosecutor and defense counsel are on hand to protect the interests they represent, they do not dominate the trial as they do in England and America. A continental trial is actually conducted by the presiding judge. He does most of the questioning. His duty is similar to that of the investigating magistrate; he must get at the real facts in every case. He examines the witnesses, the experts, the accused, and does whatever is necessary to clear up the criminal charge.

In this inquisitory criminal procedure the expert witness appears fundamentally as an auxiliary to the investigating magistrate or to the trial judge in getting at the truth. In most cases it is completely within the discretion of the investigating magistrate or trial judge as to whether or not he will in any particular instance order the employment of an expert. The prosecuting attorney or the defendant may de-

-A.B., I925, LL.B., 1928, Harvard University. Member of the New York Bar. Consultant to the National Commission on Law Observance and Enforcement (Wickersham Commission), 1930-3x, Columbia Criminological Survey, r931, Massachusetts Crime Commission, r933, Committee on Government Statistics, 1934, Liquor Study Committee, 1934. Social Science Research Council Fellow, 1932-33; Harvard Law School Fellow, 1935. Author of two of the Wickersham Commission reports and contributor to legal periodicals.

${ }^{2}$ So far is this true in Germany that when the judge chooses a certain expert for specific operations, his participation in the procedure may be challenged by the parties on the same grounds as a judge may be challenged, e.g., interest, enmity, relationship, etc. StrafrRozessordowne, Art. 74. 
mand that an expert be named to make a specific investigation but the decision rests fundamentally with the judge. He will usually designate an expert, "whenever investigations are necessary which demand a special knowledge of particular sciences or arts." 2 The need for the expert arises very frequently in criminal cases on the Continent. The insanity defense is as popular with European defendants as with American, requiring the intervention of psychiatrists. ${ }^{3}$ Doctors who have specialized in legal medicine give their expert opinions on causes of death, the nature and gravity of wounds, etc. Expert accountants are called upon to unravel the complicated juggling of financial swindlers and bucket-shop operators. Toxicologists and chemists are put upon the trail of poisoners, food adulterers, etc. In one recent French case, expert physicists were used to test the claim of a Polish inventor who had obtained considerable sums of money on the strength of a purported discovery which realized the alchemist's dream of turning base metals into gold.

In order to provide some guarantees of competence in the individuals chosen as experts, official lists are drawn up in every country in the various fields of knowledge. In France, the list is drawn up annually by the Court of Appeal in each jurisdiction, on the nomination of the courts of first instance. For particular fields of knowledge, specific requisites of capacity are laid down by law. "A candidate for inscription on the medico-legal list, for example, must have practised medicine for at least five years, or have a degree in legal medicine from the University of Paris. In Italy, the "specialists," the officially designated experts, receive this title from the Ministry of Education if their education and prior experience is considered sufficient. In Germany the official list of experts is compiled by the president of the Landgericht (Superior Court of General Jurisdiction). In medico-legal matters, however, permanent consultants are named, known as Gerichtsarzte, to the courts; particularly those in the large cities. In Prussia, the state health officer (Kreisarzt) in the smaller centers serves as the medico-legal consultant for the court of his district. In university cities, these Gerichtsarzte are frequently the professors of legal medicine of the medical faculty.

In all three countries the institutes of legal medicine ${ }^{5}$ are frequently called upon for assistance in medico-legal matters. So significant in this field is the work of these

${ }^{2}$ Codice di Procedura Penale (r93i) Art. 314.

s The latter may, under the German and Italian law, obtain an order from the judge for the detention of the defendant in an institution for a specified period for purposes of observation.

'In the various provinces of Prussia there exists a medical council of at least five members which acts as a sort of Court of Appeal from the opinions of the expert charged with the original investigation with a final appeal to a scientific commission in Berlin. 2 RAPMUND, DER BEAMTETE ARzT UND ARzTLICHE Sachverstandige (Berlin, rg04) 67 et seq. Special organizations also exist in Germany to provide expert assistance to the Courts on particular matters. In copyright disputes, for example, there is áttached to the Ministry for Science, Art, and Education, a commission for each one of the five principal branches of artistic activity, composed of the leaders in the various fields.

${ }^{8}$ The first institute of legal medical was founded in Vienna in 1804 . Vienna's example was followed by the medical faculties of many universities throughout Europe. The professor of legal medicine is usually put in charge of the institute. Many institutes are handicapped by inadequate facilities and funds.

The discussion of medico-legal institutes herein is based on materials presented in a volume on the 
institutes, which have no counterpart in this country, that, at the risk of digression, their activities will be briefly depicted at this point.

The medico-legal institute performs two functions, in addition to its research activities. First, it provides expert assistance to the judicial and administrative authorities in medico-legal matters. The autopsies in all cases of homicides, suspected deaths, or suicides are usually performed at these institutes. In addition their aid is frequently sought by the police, prosecutors, and judicial authorities whenever scientific methods must be used in criminal investigation. The making of toxicological investigations in suspected poisonings, the identification of firearms, the examination of the victims of sexual crimes, of blood-stains, seminal stains, and hair, are among the routine duties of these institutes. The expert opinion of the institute personnel is eagerly sought in matters pertaining to the civil law as well as in connection with the criminal law. They may be called in to determine the causes of accidents, the nature of injuries, the parentage of bastard children, the origin of fires, etc. In five provinces of Northern Italy, a large part of the insurance work is done by the officials of the medico-legal institute of Siena.

The position of the medico-legal institutes in the administration of civil and criminal justice is either authorized by law or is the result of informal arrangements between the members of the institutes and the administrative and judicial authorities. In Denmark, for example, the law provides that all the legally required autopsies for two-thirds of the country, shall be performed at the medico-legal institute of Copenhagen. The Danish laws have also made the institute the medico-legal center for the entire country in other matters. In Italy, on the other hand, no law requires that the administrative and judicial authorities employ the institutes for specific inquiries. ${ }^{\circ}$ Nevertheless the authorities have recognized the expert character of the institute's personnel and methods and have made increasing use of their resources. In other European countries, as in Germany and Austria, much medico-legal work has come to the institutes through the position of their directors and assistants as official experts for the courts.

The institutes perform a second function in serving as a center for the teaching of legal medicine. Legal medicine has come to have a growing importance in the medical school curriculum. Many European universities now require their medical school students to take a course in this subject before graduation. Many countries also require their public health officers and their state doctors to study and be examined in legal medicine as a preliminary to appointment. The growing appreciation of the importance of a knowledge of legal medicine for the administration of civil and criminal justice has also fostered the establishment of courses for law students. Special courses are also arranged in some countries for police officials,

subject published by the Rockefeller Foundation. Rockefeller Foundation, Methods and Problems of Medical Education (9th series, rg28).

-A specific provision of the prior Italian Code of Criminal Procedure, Codice di Procedura Penss (Igr4) Art. 209, gave to the directors and assistants of these institutes a preferential status. 
judges, and prosecutors. The teaching is done at the medico-legal institutes. Students are usually given both a theoretical course of lectures and some practical contact with the day-to-day materials that pass through the institute. Many of the institutes have excellent collections of pertinent medico-legal materials (museums) which facilitate the task of teaching.

To return to the expert and his work, this usually begins in the preliminary stages when the case is being prepared for trial. The task he must do is set out for him by the investigating magistrate. The expert then proceeds under no control except that of the magistrate to make the necessary tests upon which his opinion will be based. The defendant, except as he himself is the subject of these tests, may not be present at these proceedings. Nor may he designate an expert of his own choosing to supervise or to observe the operations of the official expert. The defendant may, of course, choose an expert to assist him in the preparation of his defense. But the latter will not necessarily have a chance to make an independent examination of the persons or things which are the subject of the "expertise." The Italian Code specifically provides ${ }^{7}$ that even where such examination is possible, it may only be had if the investigating magistrate consents thereto. In any event, the closing of the preliminary investigation must not be delayed by this privilege granted to the defense. Thus the defense expert will have to assume in most cases the correctness of the experiments of the official expert. The defense expert will not have a chance to repeat them. His functions in the preliminary procedure will be limited therefore to a criticism of the written report which the official expert makes to the investigating magistrate. The defense expert may also submit a report to the magistrate, embodying his criticisms and opinions, which will be added to the dossier of the case. But this report, since it is a partisan document, will not have the same weight in the determination of the rest of the procedure as will the report of the official expert.

It is only at the trial, in a French and German court, that the defence has any very effective chance to impugn the findings of the official expert. The latter must testify orally. The written report he made in the preliminary stage serves as a basis for his examination. He may therefore be submitted to cross-examination by defense counsel who may also call his own experts to contradict the official expert. Thus the battle of experts is not avoided by French and German procedure. The lines, however, are somewhat differently drawn than in America. Both experts are examined originally by the presiding judge and not by the ptosecutor or defense counsel. Only when the judge completes his examination may supplementary questions be put by the prosecutor and the defense. Moreover, the French and German experts are not confined by any restrictive rules of evidence in giving their opinions. French and German evidentiary rules are much more liberal than Anglo-American. Experts in Europe are not strait-jacketed by hypothetical questions.

Only the Italians have provided a means of avoiding the battle of experts. Instead

${ }^{7}$ Codice di Procedura Penal (1931) Art. 324. 
of having the experts testify orally as to their findings, their written reports are read. The official expert may, however, be called by the prosecution or the defense to elucidate orally his written report. The defense expert does not have the same privilege. ${ }^{8}$ In the Italian view, he is a mere technical assistant to the defense and anything which he has to contribute by way of oral discussion may be brought out in the arguments of counsel at the end of the trial.

There is much dissatisfaction with the organization of expert testimony on the continent. In France it is stated that the vices of the "expertise" are one of the principal sources of judicial error. ${ }^{9}$ There are many reasons for this dissatisfaction. In the first place, the existence of an official list from which expert witnesses must be drawn does not necessarily insure competence in the expert chosen by the judge. Inscription on the list gives the individual a certain standing and prestige in his profession. As a consequence, in France at least, political and other extra-legal influences which have nothing to do with the merit of the candidate are used to obtain inscription on the list.

The designation of incompetent experts by the judge would not be so serious if the official and the defense experts were on the same plane. But as we have seen, the defense expert is relegated to a secondary rôle to a greater or lesser extent in every country. The opinion of the official expert, since it is supposed to emanate from an impartial source, is all important. Although investigating magistrates and trial judges are free to make their independent evaluations of the expert's findings, they are usually incapable of doing so. They do not have the necessary technical training to make an authentic criticism. The report of the official expert is theretore usually conclusive.

Because of the decisive influence of the report of the official expert, some supervision over his operations by the defense becomes absolutely necessary. Even the best of experts may make mistakes. Yet the defense at the present time has no check upon the accuracy of the operations which are the basis of the expert opinion. A proposed French reform would therefore provide the necessary controls by the defendant over the work of the official expert. The investigating magistrate would be required to appoint two experts, an official and a defense expert. All the operations prior to the formation of the opinion would be performed by both men. If the two experts come to different conclusions then a third expert will be appointed by the magistrate. This procedure is already used in France in special cases, such as adulteration of food, frauds in merchandise, and unlawful speculation. ${ }^{10}$ French reformers wish to generalize this system and make it.the ordinary procedure.

${ }^{8}$ Codice di Procedura Penal (1931) Art. 451, 416. Only where an "expertise" is ordered in the trial stage by the trial judge, may the defense put an expert on the stand to give his observations on the opinion of the official expert. But there is an absolute prohibition against any discussion between these experts. Id., Art. 417 .

${ }^{8}$ Lailler et Vonoven, Les Erreurs Judiciaires et Leurs Causes (1897) 97 et seq.; Tchernopf et Schonfeld, L'Expertise Judiciaire en Matiere Penale (1932) 101 et seq.; Lescocur, L'Expertise Con. tradictoire (1905) 29 Revue Penitentiaire, 1216-1225.

${ }^{10}$ Tchernoff et Schonfeld, op. cit. supra note 9,226 et seq. 
An organization of expert testimony such as the French propose was provided by the Italian Code of $1914 .{ }^{11}$ The discussions preceding the enactment of the Fascist Code of 193 r reveal no real dissatisfaction with its functioning. But it has been abolished, ostensibly to prevent experts for the defendant from deceiving the judges. According to the Fascist reformers, it is the defendant's expert who is most interested in concealing the truth. He is therefore reduced to a mere "technical consultant." His name and his rôle warn the judge that he is simply an auxiliary to the defense to whose conclusions no more importance should be attached than to the arguments of defense counsel. ${ }^{12}$

The proposed French system and the Italian system of $19 \mathrm{I}_{4}$ in the organization of expert testimony, eliminates the fiction of impartiality upon which so much of European procedure is based. Defendants in European criminal procedure have fewer rights than in American procedure, due partly to the fact that judges perform many of the functions with which the parties are charged in this country. The judges are supposed to take an impartial view of the case, taking care of the interests of both prosecution and the defense. But it is extremely difficult for the European investigating magistrate or trial judge to avoid the psychology of the prosecutor who is a colleague, member of the same judicial corps. Most defendants are guilty anyway-in France 9o per cent of the defendants who come before the courts of first instance (tribunaux correctionnels) are found guilty-and judges soon conceive their functions in terms of demonstrating guilt. This attitude is easily transferred to the official expert who is in frequent contact with these magistrates. He, too, may easily conceive his rôle in terms of bringing in an opinion which is favorable to the prosecution. He, too, is interested in punishing the guilty and is aware that most defendants are found guilty. With such an attitude the dice are loaded against the defendant. Expert opinion is sought which is definitely hostile to him, and in the formation of it he has no control. Only when he is permitted to have an expert represent him on the same plane as the official expert will his interests be adequately protected.

It is apparent that France and Italy are as much beleaguered by the problem of expert testimony as is the United States. France wishes to introduce a contentious element in the organization of its "expertise." Italy banishes contentiousness because it tends to raise a doubt. Certainty can always be obtained if only one positive opinion is permitted. In America, where the expert as the auxiliary to the court is not altogether unknown, there is a desire to generalize this system, its proponents being obviously unaware of the difficulties Europe has experienced.

"Codice di Proceduri Penale (igi4) Art. 208, $211,212$.

138 Lavori Preparatori (1929) 63-64. 